\title{
Approaches to define canine distemper virus with neurological symptoms on the basis of molecular characterization of hemagglutinin and fusion genes
}

Hasbi Sait SALTIK ( $\sim$ hasbi.saltik@gmail.com )

Mehmet Akif Ersoy University: Burdur Mehmet Akif Ersoy Universitesi https://orcid.org/0000-00023283-7062

\section{Kamil ATLI}

Mehmet Akif Ersoy University: Burdur Mehmet Akif Ersoy Universitesi

\section{Research Article}

Keywords: Canine, Distemper, hemagglutinin, fusion, glycosylation, neurological, phylogeny

Posted Date: February 3rd, 2022

DOI: https://doi.org/10.21203/rs.3.rs-1306209/v1

License: (c) (i) This work is licensed under a Creative Commons Attribution 4.0 International License.

Read Full License 


\section{Abstract}

Canine distemper virus (CDV), which causes severe infections in all domestic and wild carnivores, is transmitted by all secretions and excretions of infected animals. Despite the regular vaccination against it, CDV still manages to circulate in nature and is a worldwide problem in dogs. For many years in the world, the virus managed to circulate in nature. The current investigation aims to identify and characterize CDV in dogs with neurological symptoms and to determine whether CNS symptoms and phylogenetic data might be used to differentiate between CDV strains. The medical records of 35 dogs with central nervous system (CNS) symptoms were examined. An ELISA kit was used to identify CDVspecific IgG antibodies in all of the dogs' serum samples. RT-PCR confirmed the presence of CDV nucleic acid in 30 of these dogs. Of the RT-PCR-positive samples, 6 were randomly chosen for further sequencing, sequence comparisons, and phylogenetic reconstructions. Genes encoding the Hemagglutinin $(H)$ and Fusion (F) proteins were partly sequenced and compared to other CDVs from throughout the world, including vaccine strains. The maximum likelihood method was used to build a phylogenetic tree using $\mathrm{CDV} \mathrm{H}$ and $\mathrm{F}$ gene nucleotide sequences. According to phylogenetic analysis of partial $\mathrm{H}$ and $\mathrm{F}$ gene nucleotide sequences, the field CDVs in this investigation were unique and different from the vaccination strain. The phylogenetic analysis indicated that all Turkish CDV strains that induced CNS symptoms belonged to the European CDV clade. While the intricacy of the CNS and the complexities of glycosylation pathways may provide significant challenges to infections, future research will bring significant benefits by identifying evolutionarily conserved activities of $\mathrm{N}$-glycosylation in CDV-infected dogs.

\section{Introduction}

Canine distemper virus (CDV), is an enveloped, negative-sense, single-stranded RNA virus that belongs to the morbillivirus genus of the Paramyxoviridae. (Afonso 2016). CDV can cause infections in families of Canidae, Felidae, Hyaenidae, Mustelidae, Procyonidae, Ursidae, and Viverridae (Guo et al. 2013; MartinezGutierrez and Ruiz-Saenz 2016). Despite the presence of a susceptible broad range of animals, the main reservoir for CDV has been reported as dogs that belong to the Canidae family (Kapil and Yeary 2011). Commonly, the viral infection caused by CDV is associated with respiratory, gastrointestinal, and nervous system disorders in carnivores. Several studies on the clinical and pathological aspects of different kinds of CNS symptoms in dogs have been published over the years (Headley et al. 2009; Pratakpiriya et al. 2017; Trogu et al. 2021). A compilation and summary of the clinical information on canine CNS symptoms has been provided in the articles on this subject. There have been few attempts to analyse how effectively CNS illnesses may be distinguished from each other based on clinical and molecular data. The genome of CDV consists of genes for $\mathrm{C}$ and $\mathrm{V}$ non-structural proteins, and six structural proteins: nucleocapsid protein $(N)$, haemagglutinin $(H)$, fusion protein $(F)$, phosphoprotein $(P)$, matrix protein $(M)$ and large protein $(L)$. The non-structural proteins $(C)$ and $(V)$ are produced by an alternative open reading frame in the $P$ gene (Diallo 1990; von Messling et al. 2006). Previous studies have revealed that the gene regions encoding the $\mathrm{H}$ and $\mathrm{F}$ proteins are subjected to a higher variability while the genes encoding N, P, M, and L proteins are highly conserved (Haas et al. 1999; Martella et al. 2006). The H 
protein was reported to be 607 amino acids (aa) in length and has an $1824 \mathrm{bp}$ gene size. Twelve putative N-glycosylation sites (19-21, 149-151, 309-311, 339-341, 391-393, 422-424, 456-458, 517-519, 542-544, $584-586,587-589,603-605)$ are conserved in the H protein (Liu et al. 2019). It encodes a type II integral membrane glycoprotein that helps in the attachment of the virus to the host cell receptors (Diallo 1990; Martella et al. 2006; Sawatsky and von Messling 2010). The involvement of the H protein's glycans is one component that has received little attention. Glycans are primarily involved in protein folding and posttranslational modification. N-linked glycosylation is one of the most prevalent types. Within the conserved pattern Asn-X-Ser/Thr, a high mannose core is linked to the amide nitrogen of asparagine (N). The CDV F gene open reading frame encodes 662 amino acids (aa) in length and a 1989 bp gene size, comprising the regions Fsp (aa 1-135), F2 (aa 136-224), and F1 (aa 225-662). It encodes type I integral membrane protein excluding 135 aa in length $\mathrm{N}$-terminal signal peptides (Romanutti et al. 2016). The membrane protein plays an essential role in fusion between the virus and the infected cells or in the circulation of the virus among the host. Therefore, $\mathrm{H}$ and $\mathrm{F}$ genes encoding proteins are suitable for genetic analysis (von Messling et al. 2001). CDV genotypes have been classified into America-1 (vaccine strains), America-2, Asia-1, Asia-2, Arctic-like, Europe, Europe Wildlife, South Africa, and South America clusters based on nucleotide alignment of $\mathrm{H}$ and $\mathrm{F}$ proteins (Freitas et al. 2019; Koç et al. 2021; Lan et al. NT 2005; Lednicky et al. 2004; Mira et al. 2018; Romanutti et al. 2016). Haemagglutinin (H) and fusion (F) glycoproteins constitute the viral envelope and are essential for cellular infection by binding to signalling lymphocyte activation molecule (SLAM) and CD46 cellular receptors (Tatsuo et al. 2001). The $\mathrm{H}$ protein binds to one or more receptors, causing cellular attachment and activation of the $\mathrm{F}$ protein by tissue-specific proteases, terminating in cellular infection. Hence, these proteins play a vital role in determining host range and tropism (Seki et al. 2003). Complete $\mathrm{H}$ gene sequence studies have found widely distant groups of CDV isolates, although some connections among these lineages remain uncertain (Trogu et al. 2021). To our knowledge, the patterns of selection or recombination, as well as their relationship to the many cases of emergence in dogs with neurological symptoms, have not been investigated in any study to our knowledge. In the present study, the medical records of 35 dogs with symptoms of the CNS were evaluated, as was the sequencing of the $\mathrm{H}$ and $\mathrm{F}$ genes of the virus. The purpose was to determine whether CDV strains can be detected by the prevalence of their symptoms as a group and to search for criteria that would be helpful for recognizing CDV strains. Analyses of the CDV H protein have identified twelve $\mathrm{N}$-glycosylation sites. The importance of glycans in CDV H protein is likely to extend beyond protein modification and folding. Their involvement in the pathogenesis of neural cell adhesion, axonal targeting, neural stimulation, viral receptor binding and fusion with virus-cell are all possible roles (Vigerust and Shepherd 2007).

\section{Materials And Methods}

\section{Sampling}

A total of 35 tested animals exhibited clinical symptoms of CNS at the time of sample collection. The dogs tested in this study had never been vaccinated with any CDV vaccines. In 2020, peripheral blood samples were collected into sterile tubes containing etilendiamintetra-asetat (EDTA) from the 
antebrachial cephalic vein of 35 dogs. Blood samples with EDTA were centrifuged at $4^{\circ} \mathrm{C}$ at $1500 \mathrm{xg}$ for 10 minutes for buffy coat separation. For $5 \mathrm{~min}$, blood serum samples were centrifuged at $3000 \mathrm{rpm}$. Serum samples were transferred to sterile microtubes at a volume of $2 \mathrm{~mL}$. Until testing, the samples were kept at $-80^{\circ} \mathrm{C}$. Before testing, all serum samples were inactivated for $30 \mathrm{~min}$ at $56^{\circ} \mathrm{C}$. The dogs were suspected of CDV infection by determination of their pre-vaccination status in private veterinary clinics. During the sampling period, the individual features of all dogs were recorded according to their owners' declarations and clinical observations. Anamnesis and clinical symptoms were taken into consideration as risk factors in this study.

\section{CDV-specific IgG ELISA detection}

Dogs with CNS symptoms were sampled for further study based on an abnormal neurologic examination and were diagnosed by ELISA-IgG for the initial time. An indirect ELISA was used to detect CDV-specific IgG antibodies in serum samples. CDV-specific IgG was detected using a commercially available kit (Agrolabo, Italy). The test was carried out in accordance with the manufacturer's recommendations.

\section{Extraction and Reverse Transcriptase Polymerase Chain Reaction (RT-PCR)}

Total RNA was extracted from the samples and commercial vaccine, using RiboEx ${ }^{\mathrm{TM}}$ (GeneAll®, Korea) according to the manufacturer's instructions. Extracted samples were used to amplify the targeted $\mathrm{N}$ protein-encoding gene by RT-PCR assay on a Thermo Cycler (Applied Biosystems ${ }^{\mathrm{TM}}$, USA). Primer sets and cycling conditions were used as previously described by Frisk et al. (1999), with only slight modifications. The PCR cycling conditions were $\mathrm{CDNA}$ synthesis at $50^{\circ} \mathrm{C}$ for $15 \mathrm{~min}$, pre-denaturation at $94^{\circ} \mathrm{C}$ for $1 \mathrm{~min}, 35 \mathrm{cycles}$ of $1 \mathrm{~min}$ at $94^{\circ} \mathrm{C}, 2 \mathrm{~min}$ at $59^{\circ} \mathrm{C}$, and $1 \mathrm{~min}$ at $72^{\circ} \mathrm{C}$, and a post-extension at $72^{\circ} \mathrm{C}$ for $7 \mathrm{~min}$. For the $\mathrm{H}$ gene, RT-PCR cycling conditions were $5 \mathrm{~min}$ at $95^{\circ} \mathrm{C}$ pre-denaturation, 35 cycles each of $94^{\circ} \mathrm{C}$ for $1 \mathrm{~min}, 60^{\circ} \mathrm{C}$ for $1 \mathrm{~min}$, and a post-extension of $72^{\circ} \mathrm{C}$ for $10 \mathrm{~min}$ (Lan et al. 2005). For the $\mathrm{F}$ gene, RT-PCR cycling conditions were $5 \mathrm{~min}$ at $95^{\circ} \mathrm{C}$ pre-denaturation, 35 cycles each of $94^{\circ} \mathrm{C}$ for $1 \mathrm{~min}$, $45^{\circ} \mathrm{C}$ for $1 \mathrm{~min}$, and a post-extension of $72^{\circ} \mathrm{C}$ for $10 \mathrm{~min}$ (Romanutti et al. 2016). All primers were shown in Table 1 together with their nucleotide positions and amplicon sizes. In all tests, cDNA was synthesised using the Revertaid ${ }^{\mathrm{TM}}$ First Strand cDNA Synthesis Kit (Thermo Scientific ${ }^{\mathrm{TM}}$, Germany) according to the manufacturer's instructions. The electrophoresis of $5 \mu$ l of PCR products was performed in $2 \%$ agarose gel. Sterile purified water and CDV RNA (extract from a commercial vaccine) were used as negative and positive controls, respectively.

\section{Table 1}

\section{Sequence and Phylogenetic Analyses}

All positive PCR product samples with expected size of $1046 \mathrm{bp}$ for the $\mathrm{H}$ gene and $797 \mathrm{bp}$ for the $\mathrm{F}$ gene were sequenced in both directions by a commercial company (Macrogen; BMLabosis, Turkey). The obtained sequences of CDV partial $\mathrm{H}$ and $\mathrm{F}$ genes were subjected to BLASTn to compare for sequence identities/variations with other sequences of CDV strains around the world present in the GenBank (NCBI) 
database (Altschul et al. 1990; Benson et al. 2012). Further, amino acid sequences were subjected to multiple alignment with BioEdit software (v.7.2) using the Clustal-W method (Hall 1999; Thompson et al. 1994). The deduced amino acid sequences of the genes along with the other CDV strains from different geographical regions were used to construct the phylogenetic trees with bootstrap values calculated with 1000 replicates (Fig. 4-5) by using the maximum likelihood (ML) method in MEGA 11 software (Tamura et al. 2021). Additionally, positive sequences were submitted to GenBank through the Banklt interface to receive an accession number. Similarity and identity rates regarding bet sequences have been calculated in MatGAT 2.0 (Campanella et al. 2003).

\section{Nucleotide sequence accession numbers}

The GenBank accession numbers of the sequences used in this study are as follows

\section{H gene}

GQ214373 (Austria), KR002661 (Switzerland), AY386315 (USA), DQ494317 (Italy), AF478544 (Denmark), AF478550 (Denmark), DQ494318 (Italy), GQ214384 (Austria), Z47761 (Denmark), DQ889177 (Hungary), DQ494319 (Italy), AY093674 (Turkey), Z77673 (Germany), Z77671 (Germany), HM443723 (Italy), HM443718 (Italy), KT588923 (Turkey), DQ228166 (Italy), Z47759 (Denmark), AY498692 (USA), FJ392651 (Argentina), KT266736 (Mexico), JN215475 (Uruguay), KF835422 (Colombia), KF835411 (Colombia), EU098103 (Brazil), EU098104 (Brazil), EU098105 (Brazil), EU098102 (Brazil), AY649446 (USA), Z47762 (USA), Z54156 (USA), KC916714 (Tanzania), JN812976 (Tanzania), KC916716 (Tanzania), FJ461696 (SouthAfrica), FJ461713 (South Africa), FJ461711 (South Africa), FJ461717 (South Africa), FJ868166 (SouthKorea), EU716072 (SouthKorea), KU983521 (China), KU030831 (China), KU030832 (China) KU521345 (China), KF880678 (China), KP127966 (China) JX844220 (China) EU325730 (China), JQ732171 (China), JQ732170 (China), AB025271 (Japan), AB212965 (Japan), AB025270 (Japan), AB212730 (Japan), Z47760 (Greenlandic), AF172411 (China), FJ461709 (Nobivac PuppyDP), FJ461701 (Nobivac), FJ461702 (Vanguard Plus), FJ461710 (Canigen DHPPI), MN702774 (Canishot K5), FJ461708 (Galaxy), EU143737 (Onderstepoort), EF418782 (Lederle), GU810819 (Rockborn), AF378705 (Onderstepoort), Z35493 (Convac), AF259552 (SnyderHill) and GU266280 (Rockborn-Candur).

\section{F gene}

GQ214364 (Austria), AY386315 (USA), GQ214360 (Austria), MH430946 (Germany), AF355188 (Denmark), KT224732 (Argentina), KT224718 (Argentina), KT224719 (Argentina), AY466011 (USA), AY649446 (USA), EU716337 (USA), KP769803 (China), EF596902 (China), KJ848781 (China), JN896331 (China), KX371581 (China), KX371582 (China), KX371583 (China), EU192026 (Taiwan), AY964108 (USA), AY964112 (USA), AB476403 (Japan), AB476402 (Japan), AB475100 (Japan), AB475097 (Japan), AF378705 (Onderstepoort) and GU138403 (SnyderHill).

\section{Results}


All the blood serum samples were assigned positive via CDV IgG specific diagnostic ELISA. Blood samples from animals with CNS symptoms based on abnormal neurological findings found to be CDV positive were utilized in this investigation for further assessment. Historical abnormalities suggestive of CNS disease included seizure $n=8(22.85 \%)$, lethargy $n=2(5.71 \%)$, gait incoordination $n=10(28.57 \%)$, consciousness $n=2(5.71 \%)$, apathy/stupor $n=10(28.57 \%)$, coma $n=5(14.28 \%)$, tetraplegia $n=2(5.71 \%)$, paraparesis $n=4(11.42 \%)$, ataxia $n=15(42.85 \%)$, tremor/twitching $n=12(34.28 \%)$, blindness $n=3(8.57 \%)$, eye motility disorders $n=8(22.85 \%)$, head tilt/recumbency $n=6(17.14 \%)$, and myoclonus $n=17(48.57 \%)$ were found in dogs with CDV. In a total of seven $(20 \%)$ dogs, non-neural signs such as conjunctivitis $(\mathrm{n}=$ $1)$, fever $(n=3)$, hyperkeratosis of the foot pad or nose $(n=2)$, and gastrointestinal abnormality $(n=1)$ were observed. Information obtained from the medical records included signalment; neurologic examination findings; and results of diagnostic tests including molecular detection, sequence analysis, and phylogeny.

\section{Rt-pcr And Sequence Analysis:}

With RT-PCR, 85.71\% (30/35) of the samples tested positive for CDV based on the $\mathrm{N}$ gene from blood samples. Of the positive samples, 6 were randomly chosen from positive samples for further sequencing, sequence comparisons, and phylogenetic reconstructions. The nucleotide analysis of the $1046 \mathrm{bp}$ fragment of the $\mathrm{H}$ gene showed $98,5 \%-99,8 \%$ identity, and the $797 \mathrm{bp}$ fragment of the $\mathrm{F}$ gene showed $98,7-100 \%$ identity in our Turkish strains (Table 2). The nucleotide analysis of the $\mathrm{H}$ gene showed $91,1 \%-99,8 \%$ identity between the Turkish and vaccine strains. In the similarity matrix table, Turkish strains have shown homology rates of between $98.3-100 \%$ with each other and $88.6-100 \%$ with the vaccine strains for the $\mathrm{H}$ gene (Table 3). The closest reference sequences were the CanishotK5 (97\%) and Rockborn (97\%) strains with our HSS1_1H isolate.

The substitutions were found at positions $307,309,342,365,473,475$, and 590 of the $\mathrm{H}$ gene (Fig. 1) and $487,523,568,587,604$, and 618 of the F gene in the Turkish CDV strains (Fig. 2).

\section{N-linked glycosylation sites of the H protein of the Turkish strains:}

Glycosylation plays a crucial role in the antigenicity of many proteins. The $\mathrm{H}$ gene glycosylation sites were predicted to have twelve possible N-glycosylation sites at positions 19-21, 149-151, 309-311, 339$341,391-393,422-424,456-458,517-519,542-544,584-586,587-589$, and 603-605. A comparative analysis was done on $\mathrm{H}$ protein sequences from the six CDV field strains studied in this study. Other $\mathrm{N}$ glycosylation sites in the Turkish CDV strains were discovered in this study, in addition to the already known ones, at locations 433-435, 464-466, and 489-491 (Table 4). The putative glycosylation sites on the $\mathrm{H}$ protein were predicted by the NetNGlyc 1.0 software. The glycosylation potential and threshold were illustrated (Fig. 3).

\section{Phylogenetic Analysis}


Phylogenetic analysis was performed using the MEGA 11 software package (Tamura et al. 2021). The evolutionary history was inferred using the maximum likelihood method, and the bootstrap consensus was inferred from 1000 replicates to represent the evolutionary history of the taxa analysed, and branch lengths were indicative of genetic distances between the sequences. Trees were constructed using Kimura 2 (G) parameters. The best DNA/protein model for the construction of phylogenetic trees was selected from a model test program integrated with MEGA 11 software. Phylogenetic trees were constructed based on the nucleotide sequences of the $\mathrm{H}$ and $\mathrm{F}$ genes. In the maximum likelihood tree, the sequences in this study constituted separate clusters. CDV genotypes were classified into America- 1 (vaccine strains), America-2, Asia-1, Asia-2, Arctic-like, Europe, Europe Wildlife, South Africa, and South America clusters based on nucleotide alignment of $\mathrm{H}$ and $\mathrm{F}$ proteins. The Turkish strains joined a tight cluster of CDV strains in the European group that was separated from known CDV clades (Fig. 4-5).

\section{Nucleotide sequence accession numbers for Turkish CDV strains}

The sequences of HSS1_1H, HSS2_3H, HSS3_6H, HSS4_11H, HSS5_27H, and HSS6_33H have been deposited in Genbank for the H gene under accession numbers MW669845, MW669846, MW669847, MW669848, MW669849, and MW669850, respectively. And for F gene under accession numbers MW669851, MW669852, MW669853, MW669854, MW669855, and MW669856, respectively.

\section{Discussion}

The CDV is a highly contagious pathogen that has been widely circulated across the world. Infected dogs are a risk to other dogs since they have not been vaccinated against this agent. In this study, the CDV-N protein was successfully identified by the use of the RT-PCR technique with specific primers. Since the N protein is required for viral RNA replication, the mRNA encoding the $\mathrm{N}$ gene is highly expressed in infected cells. As a result, our study focused on the $\mathrm{N}$ gene region, which is known to be highly conserved, in order to detect the infection in the blood. (Elia et al. 2006; Pawar et al. 2011). In an uninfected dog, the presence of CDV-specific IgG in its blood serum shows that it has previously had exposure with to virus. So, 35 dogs with CDV IgG positivity and CNS symptoms were studied using the blood samples. As a result, we used blood samples from living animals as an indicator of all systems in our investigation, and we had a very high positive rate. We recommend using uncoagulated blood samples from live animals for diagnostic purposes in the future, except in the host system and tissues where the virus persists.

The most prevalent symptoms observed in our study were myoclonus, ataxia, and tremors, which were all quite typical of the neurological manifestations reported in CDV-infected dogs. Such symptoms of infected dogs have been mentioned as particularly in previous studies (Headley et al. 2009; Saito et al. 2006). The primary focus of the research was CDV-infected dogs with CNS symptoms. Doubts remain regarding whether viral persistence plays a role in the development of neurological symptoms in CDV infection. In a study comparing highly neurovirulent and non-cytolytic CDV strains that cause persistency, it was claimed that non-cytolytic CDV strains follow a different path in dog brain cells. On the other hand, in cases of distemper-induced demyelination, CDV has been shown to infect mostly astrocytes (Wyss- 
Fluehmann et al. 2010). Despite the successful clearance of CDV in white matter lesions in infected dogs, prior research with CDV has shown that the virus has the capacity to migrate to other parts of the central nervous system (CNS), resulting in new lesions every time it is re-infected (Bollo et al. 1986; Vandevelde and Zurbriggen 2005). CDV, on the other hand, may generate a persistent infection in the CNS, which is yet mostly unknown. The $\mathrm{H}$ and $\mathrm{F}$ proteins are critical to unravelling viral persistence and understanding the pathogenesis of the clinical manifestations that develop.

The $\mathrm{H}$ and $\mathrm{F}$ protein genes, which facilitate receptor binding and are significantly more variable than other morbillivirus proteins, are mainly used in molecular epidemiology research for CDV (Iwatsuki et al. 1997; Romanutti et al. 2016). Molecular studies of CDV H and $\mathrm{F}$ genes show that the distribution of CDV lineages in the world is variable. The disappearance of the old CDV strains, which are still used in vaccines and are distantly related to the new CDVs, in recent years necessitates the redesign of vaccines with newly discovered field strains (Martella et al. 2006). The Snyder Hill strain was isolated from a dog's brain in the 1950s and propagated in vivo before being modified for cell culture (Brown et al. 1972). The Onderstepoort strain was developed in North America in the 1930s, and is now widely used across the world (Haig 1956). The old CDV Onderstepoort strain, which is part of the lineage America-1, is closely connected to the majority of CDV strains (Harder and Osterhaus 1997; Lednicky et al. 2004). Our findings that only the HSS1_H1 strain of Rockborn and Canishotk5 share a high level of genetic similarity may be related to the vaccine strains' differing levels of pathogenicity or tropism.

Glycosylation is a common post-translational modification that affects protein structure, localization and trafficking, protein solubility, antigenicity, biological activity and half-life, and cell-cell interactions (Vigerust and Shepherd 2007). We studied the association between identified and putative Nglycosylation sites in the $\mathrm{H}$ gene and neurological findings. Amino acid variations in currently circulating wild-type CDV should be recognized as a potential cause contributing to a recurrence of distemper cases in well-vaccinated dog populations across the world. The function of additional potential N-glycosylation sites predicted in current wild-type CDV H proteins has to be determined (Harder and Osterhaus 1997). Similar to the previous study, our findings show that the predicted putative N-glycosylation sites and amino acid changes accumulated in the $\mathrm{H}$ protein of circulating wild-type CDV have antigenic and perhaps neuropathic consequences (Li et al. 2014). In this work, we predicted additional potential glycosylation sites with consequences for the viral life cycle and pathogenicity that were lacking in CDV and may be considered carefully when designing a new CDV vaccine. Increasing overall vaccination rates with effective vaccines that generate broad, lasting immunity must remain the top aim in distemper management, particularly in regions with high dog populations and level of exposure to carnivores.

In addition to the mutations we showed at these positions, the newly found N-glycosylation regions may be responsible for the neurological findings. It is probable that this represents just the tip of the iceberg in terms of the various and crucial functions that $\mathrm{N}$-glycosylation plays in the development of the nervous system that are yet unknown. The nervous system is governed by a diverse range of $\mathrm{N}$-glycosylated proteins, including glycoproteins found on the cell surface and in the extracellular matrix, which are involved in cell adhesion and signal transduction. Surprisingly, N-glycosylation has an effect on the 
activities of a number of these glycoproteins even when they are not located in the nervous system (Dityatev et al. 2010; Kleene and Schachner 2004).

Thus, it is vital to perform ongoing molecular epidemiological surveillance in order to discover emerging CDV variations that may be resistant to the host immune system and to analyse data. The accumulation of point mutations in the viral genome has resulted in the continuous evolution of CDV, with the following indicators: In the circumstance that novel antigenic variations with distinct molecular and antigenic features are discovered, it is possible that a comprehensive redesign of vaccination programs as well as an update of the virus strains contained in commercially available products will be required. The emergence of point mutations may also have compromised advanced molecular approaches for the detection and analysis of CDV strains that rely on perfect matching between viral DNA and test nucleotide sequences. As a result of these challenges, it is possible that these strategies will need to be modified.

\section{Declarations}

Availability of data and materials

The corresponding author declares that all information regarding this study is available online for public viewing.

Code availability

Not applicable.

\section{Funding}

This research was not supported by any grant from any funding agency/sector.

\section{Author information}

Affiliations

Department of Virology, Faculty of Veterinary Medicine, University of Burdur Mehmet Akif Ersoy University, Burdur, Turkey.

H. S. SALTIK \& K. ATLI

\section{Author' contribution}

Conceived or designed study: HSS

Performed research: HSS, KA

Analyzed data: HSS, KA 
Contributed new methods or models: HSS

Wrote the paper: HSS

Corresponding author

Correspondance to H.S. SALTIK

\section{Ethics declarations}

Statement of animal rights

All procedures were approved by the Animal Ethics Committee (AEC) at Burdur Mehmet Akif University, Turkey (No: 635, 93773921-020-E.16818).

Consent to participate

Not applicable.

Consent for publication

The Republic of Turkey Ministry of Agriculture and Forestry granted permission for publication (No: E69877819-325.04.02-E-929005).

Conflict of interest

The authors declare that they have no conflicts of interest.

\section{References}

1. Afonso CL, Amarasinghe GK, Bányai K et al (2016) Taxonomy of the order Mononegavirales: update 2016. Arch Virol 161(8):2351-2360

2. Altschul SF, Gish W, Miller W, Myers EW, Lipman DJ (1990) Basic local alignment search tool. J Mol Biol 215(3):403-410

3. Benson DA, Cavanaugh M, Clark K, Karsch-Mizrachi I, Lipman DJ, Ostell J, Sayers EW (2012) GenBank Nucleic Acids Res 41(D1):D36-D42

4. Bollo E, Zurbriggen A, Vandevelde M, Fankhauser R (1986) Canine distemper virus clearance in chronic inflammatory demyelination. Acta Neuropathol (Berl) 72:69-73

5. Brown AL, Vitamvas JA, Merry DL, Beckenhauer WH (1972) Immune response of pups to modified live-virus canine distemper-measles vaccine. Am J Vet Res 33:1447-1456

6. Campanella JJ, Bitincka L, Smalley J (2003) MatGAT: an application that generates similarity/identity matrices using protein or DNA sequences. BMC Bioinformatics 4(1):1-4 
7. Diallo A (1990) Morbillivirus group: genome organisation and proteins. Vet Microbiol 23(1-4):155163

8. Dityatev A, Schachner M, Sonderegger P (2010) The dual role of the extracellular matrix in synaptic plasticity and homeostasis. Nat Rev Neurosci 11(11):735-746

9. Elia G, Decaro N, Martella V, Cirone F, Lucente MS, Lorusso E, Livia DiT, Buonavoglia C (2006) Detection of canine distemper virus in dogs by real-time RT-PCR. J Virol gical Methods 136(12):171-176

10. Freitas LA, Leme RA, Saporiti V, Alfieri AA, Alfieri AF (2019) Molecular analysis of the full-length $F$ gene of Brazilian strains of canine distemper virus shows lineage co-circulation and variability between field and vaccine strains. Virus Res 264:8-15

11. Frisk AL, König M, Moritz A, Baumgartner W (1999) Detection of canine distemper virus nucleoprotein RNA by reverse transcription-PCR using serum, whole blood, and cerebrospinal fluid from dogs with distemper. J Clin Microbiol 37(11):3634-3643

12. Guo L, Yang SL, Wang CD, Hou R, Chen SJ, Yang XN, Liu J, Pan HB, Hao ZX, Zhang ML, Yan QG (2013) Phylogenetic analysis of the haemagglutinin gene of canine distemper virus strains detected from giant panda and raccoon dogs in China. Virol J 10(1):1-7

13. Haas L, Liermann H, Harder TC, Barrett T, Löchelt M, von Messling V, Baumgärtner W, Greiser-Wilke I (1999) Analysis of the $\mathrm{H}$ gene, the central untranslated region and the proximal coding part of the $\mathrm{F}$ gene of wild-type and vaccine canine distemper viruses. Vet Microbiol 69:15-18

14. Haig DA (1956) Canine distemper: immunization with avianized virus. Onderstepoort J Vet Res $17: 19-53$

15. Hall TA (1999) BioEdit: A User-Friendly Biological Sequence Alignment Editor and Analysis Program for Windows 95/98/NT. Nucleic Acids Symposium Series 41:95-98

16. Harder TC, Osterhaus ADME (1997) Canine distemper virus-a morbillivirus in search of new hosts? Trends Microbiol 5(3):120-124

17. Headley SA, Amude AM, Alfieri AF, Bracarense APFL, Alfieri AA, Summers BA (2009) Molecular detection of canine distemper virus and the immunohistochemical characterization of the neurologic lesions in naturally occurring old dog encephalitis. J Vet Diagn 21(5):588-597

18. Iwatsuki K, Miyashita N, Yoshida E, Gemma T, Shin YS, Mori T, Hirayama N, Kai C, Mikami T (1997) Molecular and phylogenetic analyses of the haemagglutinin $(\mathrm{H})$ proteins of field isolates of canine distemper virus from naturally infected dogs. J Gen Virol 78(2):373-380

19. Kapil S, Yeary TJ (2011) Canine distemper spillover in domestic dogs from urban wildlife. Vet Clin Small Anim 41(6):1069-1086

20. Kleene R, Schachner M (2004) Glycans and neural cell interactions. Nat Rev Neurosci 5(3):195-208

21. Koç BT, Akkutay-Yoldar Z, Oğuzoğlu T (2021) New members to Arctic-like Lineage of Canine Distemper Virus from Turkey. Comp Immunol Microb 78:101678 
22. Lan NT, Yamaguchi R, Furuya Y, Inomata A, Ngamkala S, Naganobu K, Kai K, Mochizuki M, Kobayashi Y, Uchida K, Tateyama S (2005) Pathogenesis and phylogenetic analyses of canine distemper virus strain 007Lm, a new isolate in dogs. Vet Microbiol 110(3-4):197-207

23. Lednicky JA, Dubach J, Kinsel MJ, Meehan TP, Bocchetta M, Hungerford LL, Sarich NA, Witecki KE, Braid MD, Pedrak C, Houde CM (2004) Genetically distant American Canine distemper virus lineages have recently caused epizootics with somewhat different characteristics in raccoons living around a large suburban zoo in the USA. Virol J 1(2):1-14

24. Li W, Li T, Liu Y, Gao Y, Yang S, Feng N, Sun H, Wang S, Wang L, Bu Z, Xia X (2014) Genetic characterization of an isolate of canine distemper virus from a Tibetan Mastiff in China. Virus Genes 49(1):45-57

25. Liu Y, Liu C, Liu W, Wu H, Ding H, Cao Y, Spibey N, Wang L, He W, Hao L, Li X, Tian K (2019) Isolation and sequence analysis of the complete $\mathrm{H}$ gene of canine distemper virus from domestic dogs in Henan Province, China. Arch Virol 164(8):2153-2158

26. Martella V, Cirone F, Elia G, Lorusso E, Decaro N, Campolo M, Desario C, Lucente MS, Bellacicco AL, Blixenkrone-Moller M, Carmichael LE, Buonavoglia C (2006) Heterogeneity within the hemagglutinin genes of canine distemper virus (CDV) strains detected in Italy. Vet Microbiol 116(4):301-309

27. Martinez-Gutierrez M, Ruiz-Saenz J (2016) Diversity of susceptible hosts in canine distemper virus infection: a systematic review and data synthesis. BMC Vet Res 12(1):1-11

28. Mira F, Purpari G, Di Bella S, Vicari D, Schirò G, Di Marco P, Macaluso G, Battilani M, Guercio A (2018) Update on canine distemper virus (CDV) strains of Arctic-like lineage detected in dogs in Italy. Vet Ital 54(3):225-236

29. Pawar RM, Raj GD, Gopinath VP, Ashok A, Raja A (2011) Isolation and molecular characterization of canine distemper virus from India. Trop Anim Health Prod 43(8):1617-1622

30. Pratakpiriya W, Teh APP, Radtanakatikanon A, Pirarat N, Lan NT, Takeda M, Techangamsuwan S, Yamaguchi R (2017) Expression of canine distemper virus receptor nectin-4 in the central nervous system of dogs. Sci Rep 7(1):1-9

31. Romanutti C, Calderón MG, Keller L, Mattion N, La Torre J (2016) RT-PCR and sequence analysis of the full-length fusion protein of canine distemper virus from domestic dogs. J Virol Methods 228:7983

32. Saito TB, Alfieri AA, Wosiacki SR, Negrao FJ, Morais HSA, Alfieri AF (2006) Detection of canine distemper virus by reverse transcriptase-polymerase chain reaction in the urine of dogs with clinical signs of distemper encephalitis. Res Vet Sci 80(1):116-119

33. Sawatsky B, von Messling V (2010) Canine distemper viruses expressing a hemagglutinin without Nglycans lose virulence but retain immunosuppression. J Virol 84(6):2753-2761

34. Seki F, Ono N, Yamaguchi R, Yanagi Y (2003) Efficient isolation of wild strains of canine distemper virus in Vero cells expressing canine SLAM (CD150) and their adaptability to marmoset B95a cells. J Virol 77(18):9943-9950 
35. Tamura K, Stecher G, Kumar S (2021) MEGA11: molecular evolutionary genetics analysis version 11. Mol Biol Evol 38(7):3022-3027

36. Tatsuo H, Ono N, Yanagi Y (2001) Morbilliviruses use signaling lymphocyte activation molecules (CD150) as cellular receptors. J Virol 75(13):5842-5850

37. Thompson JD, Higgins DG, Gibson TJ (1994) CLUSTAL W: improving the sensitivity of progressive multiple sequence alignment through sequence weighting, position-specific gap penalties and weight matrix choice. Nucleic Acids Res 22(22):4673-4680

38. Trogu T, Canziani S, Salvato S, Bianchi A, Bertoletti I, Gibelli LR, Alborali GL, Barbieri I, Gaffuri A, Sala G, Sozzi E, Lelli D, Lavazza A, Moreno A (2021) Canine Distemper Outbreaks in Wild Carnivores in Northern Italy. Viruses 13(99):1-13

39. Vandevelde $M$, Zurbriggen A (2005) Demyelination in canine distemper virus infection: a review. Acta Neuropathol (Berl) 109:56-68

40. Vigerust DJ, Shepherd VL (2007) Virus glycosylation: role in virulence and immune interactions.

Trends Microbiol 15(5):211-218

41. von Messling V, Zimmer G, Herrler G, Haas L, Cattaneo R (2001) The hemagglutinin of canine distemper virus determines tropism and cytopathogenicity. J Virol 75(14):6418-6427

42. von Messling V, Svitek N, Cattaneo R (2006) Receptor (SLAM [CD150]) recognition and the V protein sustain swift lymphocyte-based invasion of mucosal tissue and lymphatic organs by a morbillivirus. J Virol 80(12):6084-6092

43. Wyss-Fluehmann G, Zurbriggen A, Vandevelde M, Plattet $P$ (2010) Canine distemper virus persistence in demyelinating encephalitis by swift intracellular cell-to-cell spread in astrocytes is controlled by the viral attachment protein. Acta neuropathol 119(5):617-630

\section{Tables}

Table 1. Oligonucleotides for RT-PCR amplification of the CDV N, H and F genes.

\begin{tabular}{|c|c|c|c|c|c|}
\hline Gene & Primers & $\begin{array}{l}\text { Nucleotide } \\
\text { position }\end{array}$ & Sequence $\left(5^{\prime}-3^{\prime}\right)$ & $\begin{array}{l}\text { Amplicon } \\
\text { size (bp) }\end{array}$ & Ref \\
\hline \multirow[t]{2}{*}{$\mathrm{N}$} & $\mathrm{N}$-for & $769-789$ & ACAGGATTGCTGAGGACCTAT & \multirow[t]{2}{*}{287} & \multirow{2}{*}{$\begin{array}{l}\text { Frisk et al } \\
1999\end{array}$} \\
\hline & N-rev & $1055-1035$ & CAAGATAACCATGTACGGTGC & & \\
\hline \multirow[t]{2}{*}{$\mathrm{H}$} & $\mathrm{H}$-for & 7948-7970 & GACACTGGCTTCCTTGTGTGTAG & & \multirow{2}{*}{$\begin{array}{l}\text { Lan et al } \\
2005\end{array}$} \\
\hline & H-rev & 8994-8969 & ATGCTGGAGATGGTTTAATTCAATCG & 1046 & \\
\hline \multirow[t]{2}{*}{$\mathrm{F}$} & F-for & $6270-6287$ & TGTGTATTCGTCTCAGA & & \multirow{2}{*}{$\begin{array}{l}\text { Romanutti } \\
\text { et al } 2016\end{array}$} \\
\hline & F-rev & 7067-7042 & TAAGACGTGTGACCAGAGTGCTTTAG & 797 & \\
\hline
\end{tabular}


Tables 2 to 4 are only available as a download in the Supplemental Files section.

\section{Figures}

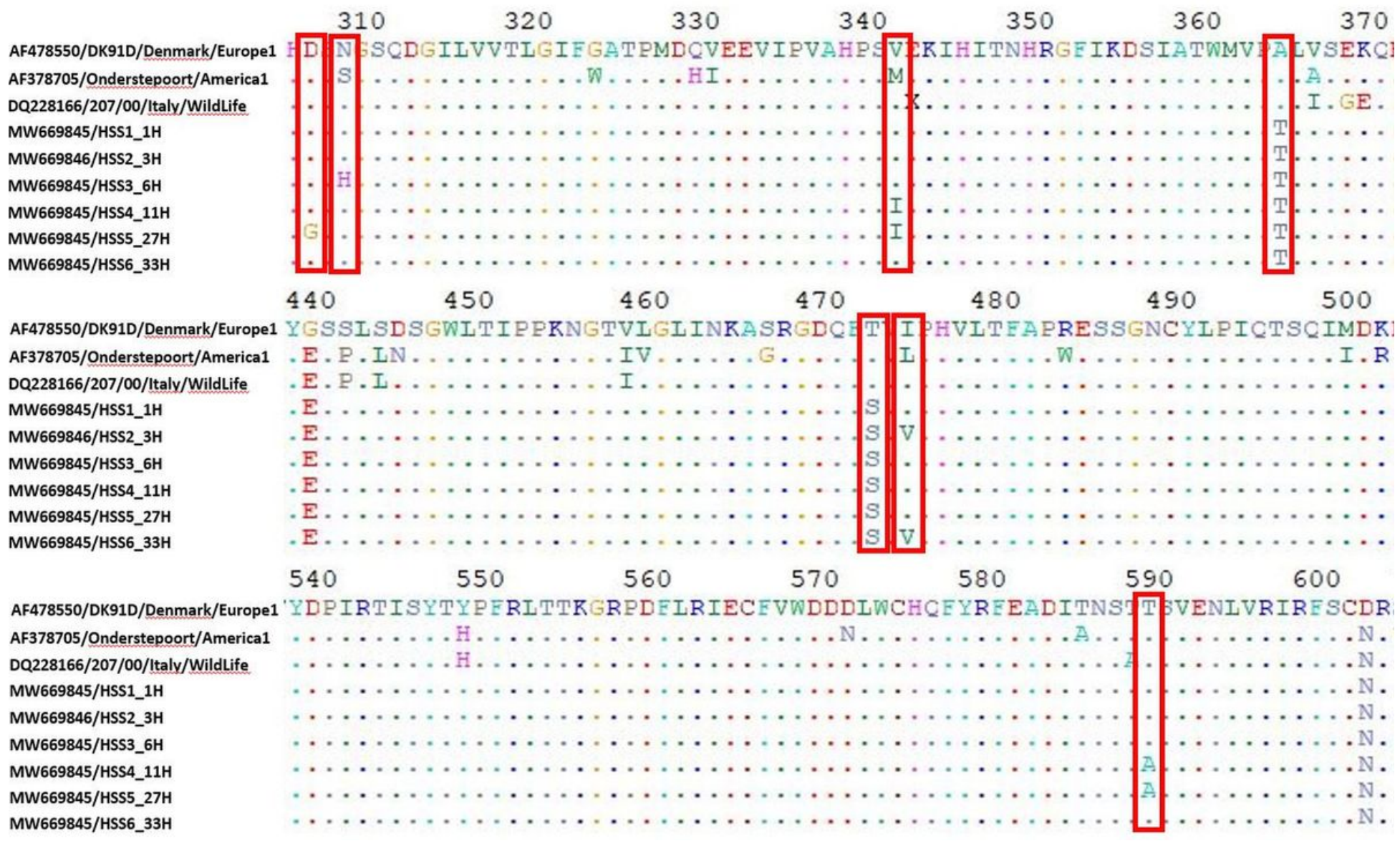

\section{Figure 1}

Alignment of the deduced amino acid sequences of the partial-length $\mathrm{H}$ gene of Turkish strains. The sequences' accession numbers are presented in the "Materials and techniques" section. Amino acid changes are shown in the rectangle box (red).

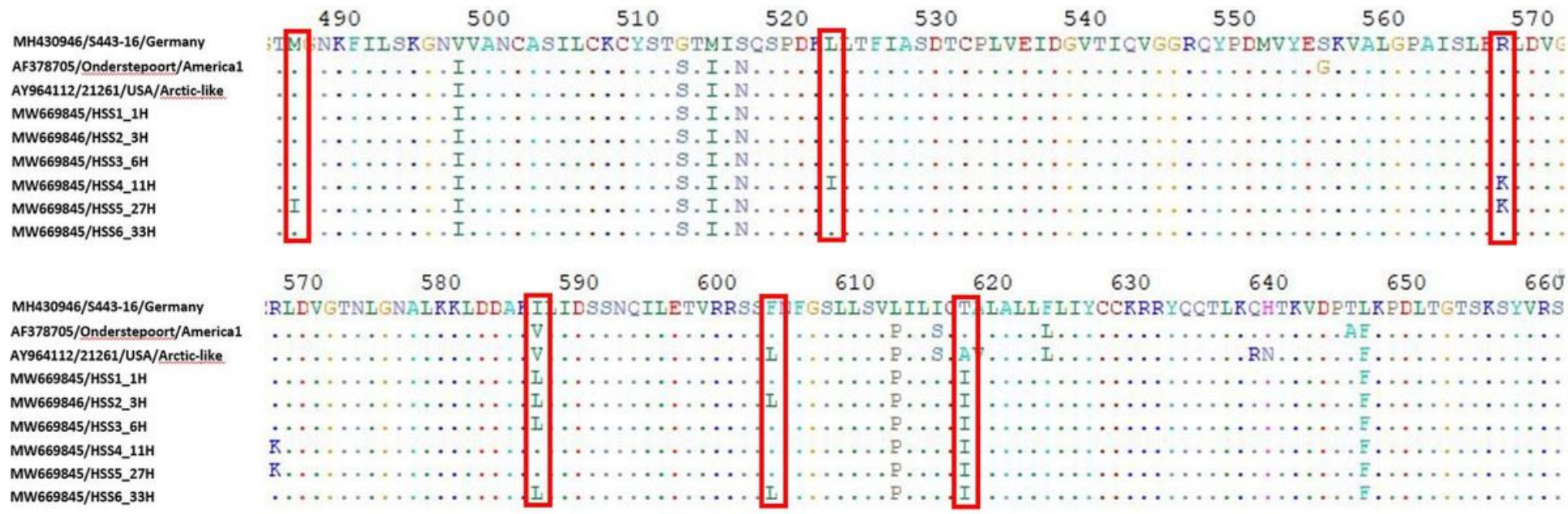


Figure 2

Alignment of the deduced amino acid sequences of the partial-length $\mathrm{F}$ gene of Turkish strains. The sequences' accession numbers are presented in the "Materials and techniques" section. Amino acid changes are shown in the rectangle box (red).
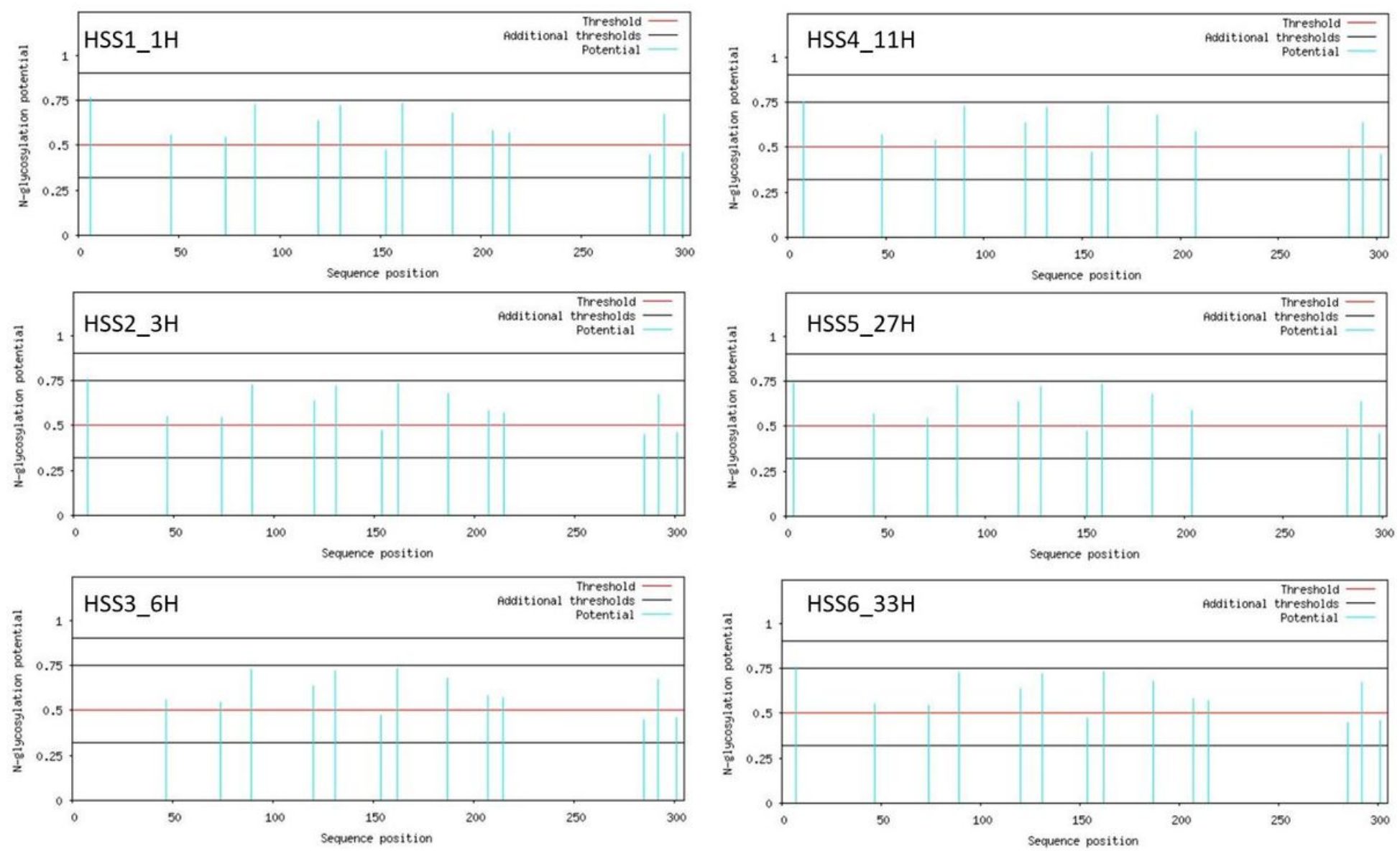

\section{Figure 3}

$\mathrm{N}$-glycosylation potentials and thresholds. 


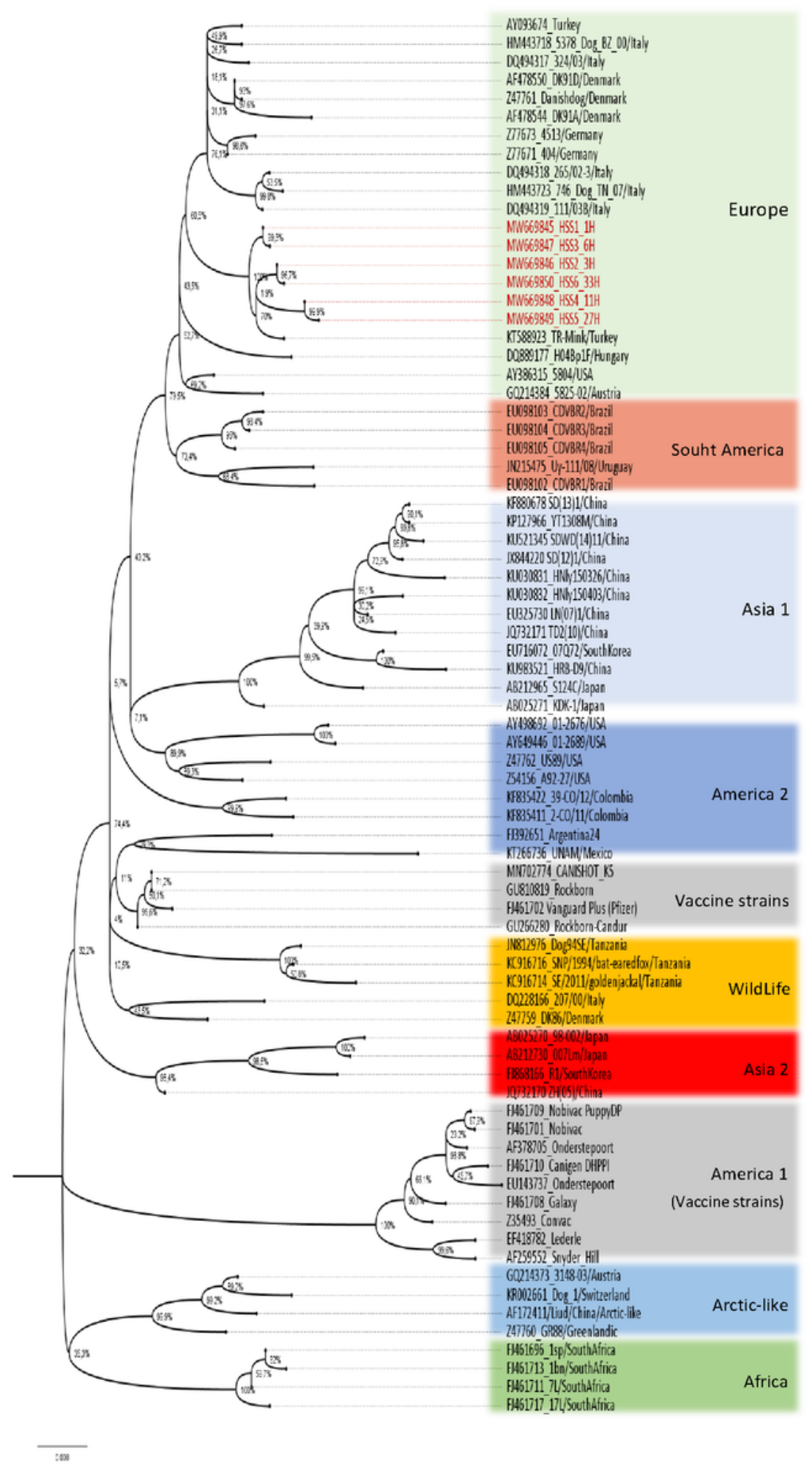

Figure 4

Nucleotide sequences and phylogenetic tree of the $1046 \mathrm{bp} \mathrm{H}$ gene sequences of Turkish CDV strains HSS1_1H, HSS2_3H, HSS3_6H, HSS4_11H, HSS5_27H and HSS6_33H compared with strains around the world obtained from the NCBI database. Bar number of base substitutions per site. 


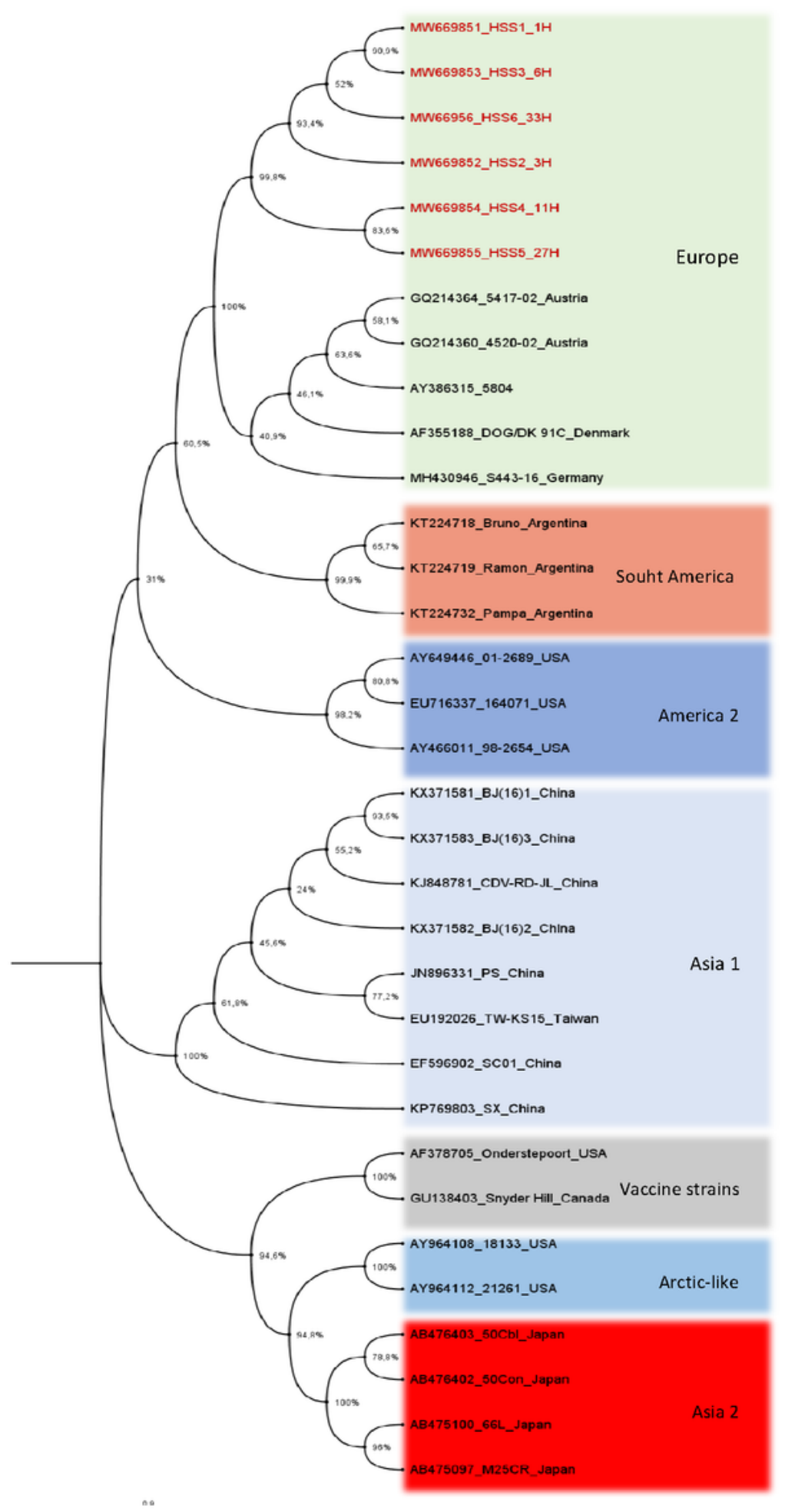

Figure 5

Nucleotide sequences and phylogenetic tree of the $797 \mathrm{bp} \mathrm{F}$ gene sequences of Turkish CDV strains HSS1_1H, HSS2_3H, HSS3_6H, HSS4_11H, HSS5_27H and HSS6_33H compared with strains around the world obtained from the NCBI database. Bar number of base substitutions per site.

\section{Supplementary Files}


This is a list of supplementary files associated with this preprint. Click to download.

- table2.docx

- table3.docx

- table4.docx 